\title{
Virus infections in bone marrow transplant recipients: a three year prospective study
}

\author{
C E Taylor, L Sviland, A D J Pearson, M Dobb, M M Reid, J Kernahan, A W Craft, \\ P J Hamilton, $S$ Proctor
}

\begin{abstract}
Over three years 81 consecutive bone marrow transplant recipients (32 allogeneic and 49 autologous) who received prophylaxis with acyclovir, were studied for symptomatic virus infection. Thirty nine infections were documented in a total of 28 patients. Thirty two infections were mild, five were moderately severe, and two were severe. Cytomegalovirus infection occurred in only six allogeneic recipients. Herpes simplex virus and varicella zoster virus infections occurred infrequently. Seven patients who were considered at the time of death to have died due to an infectious cause were studied virologically at necropsy. In only one patient was a virus infection thought to have been the cause of death.
\end{abstract}

Prophylaxis with acyclovir may have influenced the rate and clinical prominence of herpes virus infections. In this study viruses were considered to have had a relatively minor role in causing morbidity and mortality.

Bone marrow transplantation is increasingly being used in the treatment of a wide range of malignant and non-malignant disorders. ${ }^{12}$ Infections and graft versus host disease (GVHD) are the two major complications of allogeneic bone marrow transplantation. ${ }^{34}$ Viruses, especially herpes viruses, are important pathogens after bone marrow transplantation. ${ }^{56}$ Recently, prophylaxis with acyclovir has been shown to reduce the incidence of some virus infections. ${ }^{78}$

Previous studies of virus infection in bone marrow transplant recipients have focused predominantly on human herpes viruses, particularly cytomegalovirus (CMV). ${ }^{910}$ There have been few studies, however, that describe the range and effects of virus infections which can occur in bone marrow transplant recipients when prophylactic acyclovir is given.

In this investigation all patients undergoing allogeneic or autologous bone marrow transplantation in Newcastle upon Tyne over three years were studied. Patients with symptoms which might have had a viral cause were comprehensively investigated to determine the aetiological role of viruses. This report describes which viruses caused infection and their concomitaut morbidity and mortality.

\section{Methods}

All patients who received an allogeneic ( $n=32$ ) or autologous $(n=49)$ bone marrow transplant in Newcastle upon Tyne between 1 October, 1985, and 30 September, 1988 were studied. Patient details are shown in table 1. The overall mean age was 26.4 years with a range of three to 57 years. Seventeen patients were under the age of 15 years at transplantation. All patients were followed up for a minimum of three months after bone marrow transplantation or until death in the case of five autologous and six allogeneic recipients who died within the first three months of transplantation.

Twenty seven patients in the autologous group were prepared using intravenous melphalan (one dose of $3 \mathrm{mg} / \mathrm{kg}$ ) and total body irradiation ( $1050 \mathrm{cGy}$ in three fractions over 36 hours). Fourteen received melphalan alone. Eight children with neuroblastoma received a combination of vincristine, melphalan, carboplatin and etoposide with no total body irradiation. Allogeneic recipients were prepared with intravenous cyclophosphamide (two doses of $60 \mathrm{mg} / \mathrm{kg}$ ) and total body irradiation (1200 cGy in six fractions over three days). Two patients with aplastic anaemia received only cyclophosphamide (50 $\mathrm{mg} / \mathrm{kg}$ on four consecutive days). For three days before and up to 100 days after bone marrow transplantation all recipients received prophylaxis with acyclovir. This was given intravenously $(200 \mathrm{mg}$ in adults or $10 \mathrm{mg} / \mathrm{kg}$ in children three times daily) for the first 14 days after bone marrow transplantation and then orally using the same dose. If, 14 days after bone marrow transplantation the patient was either vomiting or generally unwell, intravenous acyclovir was continued until

Table 1 Diagnosis of patients undergoing bone marrow transplantation

\begin{tabular}{lcc}
\hline Diagnosis & Allogeneic & Autologous \\
\hline Acute lymphoblastic leukaemia & 13 & 9 \\
Acute myeloid leukaemia & 8 & 9 \\
Chronic myeloid leukaemia & 7 & -15 \\
Non-Hodgkin's lymphoma & 1 & 4 \\
Hodgkin's lymphoma & - & 8 \\
Neuroblastoma & - & - \\
Myeloma & 2 & - \\
Aplastic anaemia & 1 & 1 \\
Ewing's sarcoma & - & 49 \\
Rhabdomyosarcoma & 32 & $26 \cdot 7(3-57)$ \\
Total & $26 \cdot 0(4-43)$ & 2 \\
Age (years) &
\end{tabular}

Correspondence to: Dr C E Taylor

Accepted for publication 5 April 1990 
Table 2 Specimens required for virological investigation of bone marrow transplant recipients

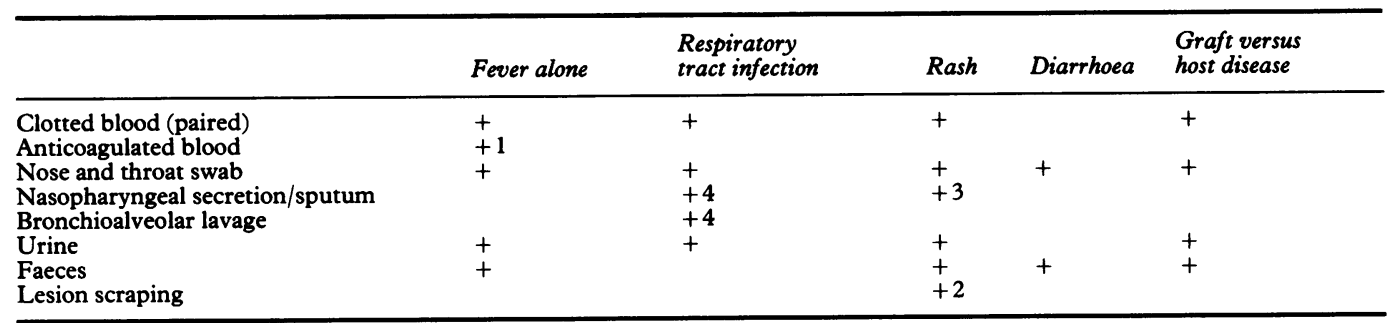

1 Fever of more than four days' duration.

2 Vesicular rash.

3 Where available.

4 As appropriate.

symptoms subsided. The allogeneic recipients were also given cyclosporin $\mathrm{A}$ as prophylaxis for GVHD for the same time period. All blood products were irradiated and CMV negative patients received products from CMV negative donors.

Virological investigations in the period after transplant varied according to the nature of the illness (table 2). Specimens were cultured for viruses by standard procedures. ${ }^{11}$ Cells from nasopharyngeal secretions, sputum, bronchoalveolar lavage (BAL) and skin lesion specimens were screened by immunofluorescent antibody techniques. ${ }^{12}$ All respiratory specimens and urines were submitted for rapid CMV diagnosis by means of immunofluorescence to detect CMV specific immediate early antigens using monoclonal antibodies. ${ }^{13}$ Faeces, urine, and vesicle fluids were also examined by electron microscopy.

Serological testing was performed routinely using the complement fixation test. For determination of serostatus the more sensitive enzyme linked immunoassay, immunofluoresence, and radioimmunoassay tests were used for antibodies to $\mathrm{CMV}$, Ebstein Barr virus (EBV), herpes simplex virus (HSV) and varicella zoster virus (VZV).

Respiratory illness was categorised as: mild (fever or a cough, or both); moderate (fever, cough, tachypnoea and changes on chest $x$ ray picture); and severe (with hypoxia or hypercapnia requiring ventilation). Diarrhoea was graded as mild ( $<500 \mathrm{ml} /$ day), moderate (500-1000 ml/day), or severe ( $>1000 \mathrm{ml} /$ day).
When GVHD was clinically diagnosed (skin rash or diarrhoea, or both, thought to be due to GVHD and requiring specific treatment) virological investigation was undertaken. Some such patients had GVHD alone, while in others viruses were isolated. Patients with GVHD in whom viruses were isolated were deemed to constitute a separate group.

Statistical analyses were performed by Fisher's exact probability test and the $\chi^{2}$ test with Yates' correction.

\section{Results}

INCIDENCE AND TYPES OF VIRUS INFECTIONS

Thirty nine virus infections comprising 33 that were confirmed virologically and six VZV diagnosed clinically, were documented in 28 symptomatic bone marrow transplant recipients (tables 3 and 4). Fifty three patients had no detectable virus infections. Seven patients experienced more than one virus infection at different times during the study period (table 5). One autologous recipient with a fever but no localising signs simultaneously had evidence of three virus infections (parainfluenza 3, coxsackie B3, and papovavirus). There was no association between the underlying reason for bone marrow transplantation and the viruses isolated.

The incidence of diagnosed virus infection was very similar in allogeneic and autologous recipients ( 15 in 32 patients and 18 in 49 patients, respectively).

Table 3 Virus infections in symptomatic allogeneic bone marrow transplant recipients

\begin{tabular}{|c|c|c|c|c|c|c|}
\hline $\begin{array}{l}\text { Case } \\
\text { number }\end{array}$ & Virus & Illness & $\begin{array}{l}\text { Severity of } \\
\text { illness }\end{array}$ & $\begin{array}{l}\text { Weeks after } \\
\text { transplantation }\end{array}$ & $\begin{array}{l}\text { Serostatus of } \\
\text { donor/recipient }\end{array}$ & Specimen \\
\hline $\begin{array}{l}1 \\
2\end{array}$ & $\begin{array}{l}\text { Cytomegalovirus } \\
\text { Cytomegalovirus }\end{array}$ & $\begin{array}{l}\text { Respiratory tract infection } \\
\text { Respiratory tract infection/ } \\
\text { graft versus host disease }\end{array}$ & $\begin{array}{l}\text { Moderate } \\
\text { Severe }\end{array}$ & $\begin{array}{r}11 \\
4\end{array}$ & $\begin{array}{l}+1+ \\
+1+\end{array}$ & $\begin{array}{l}\text { Urine } \\
\text { Anticoagulated blood }\end{array}$ \\
\hline $\begin{array}{l}3 \\
4^{\star} \\
5\end{array}$ & $\begin{array}{l}\text { Cytomegalovirus } \\
\text { Cytomegalovirus } \\
\text { Cytomegalovirus }\end{array}$ & $\begin{array}{l}\text { Respiratory tract infection } \\
\text { Fever } \\
\text { Fever/graft versus host diseasa }\end{array}$ & $\begin{array}{l}\text { Moderate } \\
\text { Mild } \\
\text { Mild }\end{array}$ & $\begin{array}{r}12 \\
8 \\
4\end{array}$ & $\begin{array}{l}+1- \\
-1- \\
-1+\end{array}$ & $\begin{array}{l}\text { Urine } \\
\text { Clotted blood } \\
\text { Anticoagulated blood, } \\
\text { nose and throat } \\
\text { swab, sputum }\end{array}$ \\
\hline $\begin{array}{l}6 \\
7 \\
8\end{array}$ & $\begin{array}{l}\text { Cytomegalovirus } \\
\text { Influenza A } \\
\text { Parainfluenza } 2\end{array}$ & $\begin{array}{l}\text { Fever } \\
\text { Respiratory tract infection } \\
\text { Respiratory tract infection }\end{array}$ & $\begin{array}{l}\text { Mild } \\
\text { Moderate } \\
\text { Mild }\end{array}$ & $\begin{array}{r}8 \\
12 \\
4\end{array}$ & $+1+$ & $\begin{array}{l}\text { Throat swab, urine } \\
\text { Sputum } \\
\text { Nose and throat swab, } \\
\text { nasoparyngeal } \\
\text { secretion }\end{array}$ \\
\hline $\begin{array}{r}9 \\
10\end{array}$ & $\begin{array}{l}\text { Parainfluenza } 3 \\
\text { Herpes simplex virus }\end{array}$ & $\begin{array}{l}\text { Respiratory tract infection } \\
\text { Stomatitis/respiratory } \\
\text { tract infection }\end{array}$ & $\begin{array}{l}\text { Mild } \\
\text { Mild }\end{array}$ & $\begin{array}{r}8 \\
18\end{array}$ & & $\begin{array}{l}\text { Nose and throat swab } \\
\text { Nose and throat swab }\end{array}$ \\
\hline $\begin{array}{l}11 \\
12 \\
13+ \\
14 \\
15\end{array}$ & $\begin{array}{l}\text { Herpes simplex virus } \\
\text { Herpes simplex virus } \\
\text { Varicella zoster virus } \\
\text { Papovavirus } \\
\text { Rhinovirus }\end{array}$ & $\begin{array}{l}\text { Respiratory tract infection } \\
\text { Stomatitis } \\
\text { Zoster } \\
\text { Fever } \\
\text { Respiratory tract infection }\end{array}$ & $\begin{array}{l}\text { Mild } \\
\text { Mild } \\
\text { Localised } \\
\text { Mild } \\
\text { Mild }\end{array}$ & $\begin{array}{r}2 \\
34 \\
29 \\
2 \\
32\end{array}$ & & $\begin{array}{l}\text { Nose and throat swab } \\
\text { Mouth swab } \\
\text { Lesion scraping } \\
\text { Urine } \\
\text { Sputum }\end{array}$ \\
\hline
\end{tabular}

$\star$ = Serological diagnosis only

$\dagger=$ Another patient had a clinical diagnosis of zoster alone. 
Table 4 Virus infections in symptomatic autologous bone marrow transplant recipients

\begin{tabular}{|c|c|c|c|c|c|}
\hline $\begin{array}{l}\text { Case } \\
\text { number }\end{array}$ & Virus & Illness & $\begin{array}{l}\text { Severity of } \\
\text { illness }\end{array}$ & $\begin{array}{l}\text { Weeks after } \\
\text { transplantation }\end{array}$ & Specimen \\
\hline $\begin{array}{l}16 \\
17 \\
18 \\
19 \mathrm{~b} \\
20 \\
21 \\
22 \mathrm{c}\end{array}$ & $\begin{array}{l}\text { Influenza A } \\
\text { Influenza A } \\
\text { Influenza A } \\
\text { Parainfluenza } 3 \\
\text { Herpes simplex virus } \\
\text { Herpes simplex virus } \\
\text { Herpes simplex virus }\end{array}$ & $\begin{array}{l}\text { Respiratory tract infection } \\
\text { Respiratory tract infection } \\
\text { Respiratory tract infection } \\
\text { Fever } \\
\text { Ulcer on tongue } \\
\text { Vesicle on thigh } \\
\text { Stomatitis }\end{array}$ & $\begin{array}{l}\text { Mild } \\
\text { Mild } \\
\text { Mild } \\
\text { Mild } \\
\text { Mild } \\
\text { Mild } \\
\text { Mild }\end{array}$ & $\begin{array}{r}7 \\
1 \\
51 \\
4 \\
2 \\
1 \\
2\end{array}$ & $\begin{array}{l}\text { BAL } \\
\text { Sputum } \\
\text { Throat swab } \\
\text { Nose and throat swab } \\
\text { Tongue swab } \\
\text { Thigh scraping } \\
\text { Nose and throat swab, } \\
\text { sputum, mouth swab }\end{array}$ \\
\hline $\begin{array}{l}23 \mathrm{a} \\
24 \\
25 \mathrm{~b} \\
26 \\
27 \mathrm{c} \\
28 \\
29 \\
30 \\
31 \\
32 \mathrm{~b} \\
33\end{array}$ & $\begin{array}{l}\text { Varicella zoster virus } \\
\text { Varicella zoster virus } \\
\text { Papovavirus } \\
\text { Rhinovirus } \\
\text { Influenza B } \\
\text { Adenovirus 1 } \\
\text { Adenovirus 1 } \\
\text { Adenovirus 6 } \\
\text { Adenovirus F type } \\
\text { Coxsackie B3 } \\
\text { Astrovirus }\end{array}$ & $\begin{array}{l}\text { Zoster } \\
\text { Varicella } \\
\text { Fever } \\
\text { Respiratory tract infection } \\
\text { Respiratory tract infection } \\
\text { Respiratory tract infection, vomiting } \\
\text { Respiratory tract infection } \\
\text { Diarrhoea } \\
\text { Diarrhoea } \\
\text { Fever } \\
\text { Diarrhoea }\end{array}$ & $\begin{array}{l}\text { Localised } \\
\text { Mild } \\
\text { Mild } \\
\text { Severe } \\
\text { Mild } \\
\text { Mild } \\
\text { Mild } \\
\text { Moderate } \\
\text { Mild } \\
\text { Mild } \\
\text { Moderate }\end{array}$ & $\begin{array}{r}24 \\
9 \\
4 \\
7 \\
2 \\
1 \\
1 \\
1 \\
3 \\
4 \\
11\end{array}$ & $\begin{array}{l}\text { Lesion scraping } \\
\text { Lesion scraping } \\
\text { Urine } \\
\text { Sputum } \\
\text { Sputum } \\
\text { Faeces } \\
\text { Nose and throat swab } \\
\text { Faeces } \\
\text { Faeces } \\
\text { Faeces } \\
\text { Faeces }\end{array}$ \\
\hline
\end{tabular}

$\mathrm{a}=$ Five other patients had a clinical diagnosis of zoster alone.

band $c=$ Simultaneous infection in the same patient.

The largest numbers of viruses causing symptoms were found in two main groups: herpes viruses-VZV $(n=9), \mathrm{CMV}(\mathrm{n}=6), \mathrm{HSV}$ $(n=6)$ and respiratory viruses-influenza $A$ and $B$ viruses $(n=5)$, parainfluenza viruses 2 and $3(n=3)$, and rhinoviruses $(n=2)$. Miscellaneous infections with adenoviruses $(n=4)$; papovavirus $(n=2)$; coxsackie virus B3 $(n=1)$ and astrovirus $(n=1)$ also occurred.

The serological state of the recipients with herpes viruses before transplantation was similar in allogeneic and autologous patients (table 6 ). Over $80 \%$ of all recipients were seropositive to $\mathrm{EBV}, \mathrm{HSV}$, and VZV, and more than $50 \%$ had antibodies to CMV.

Overt CMV infection only occurred in six allogeneic recipients and was associated with a lower respiratory tract infection in three. There was no clear association between CMV infection and the serological state of the donor and recipient. In contrast to allogeneic recipients, $\mathrm{CMV}$ infection was not detected in autologous recipients ( $p=0.006$, Fisher's exact test).

Infections with HSV occurred occasionally, being documented in only six patients, and were not progressive. VZV infection occurred in nine patients, seven of whom were autograft recipients $\left(p=0.2, \chi^{2}\right.$ test). Eight infections were manifest as localised zoster and one as chicken pox.

Paired sera were available for testing by complement fixation test in 15 patients. Diagnostic rises in complement fixation titres were recorded in four of 11 infections in allogeneic recipients and in none of the four infections in autologous recipients (data not shown).

Papovavirus was associated with fever in two patients. Paired sera were available only from

Table 5 Number of episodes of virus infection from each patient

\begin{tabular}{lll}
\hline Number of episodes & Allograft $(n=32)$ & Autograft $(n=49)$ \\
\hline 0 & 21 & 37 \\
1 & 8 & 8 \\
2 & 2 & 2 \\
3 & 1 & 2 \\
\hline
\end{tabular}

the allogeneic recipient, and a serological response to JC virus was shown. The symptomatic autologous recipient who excreted papovavirus was simultaneously infected with two other viruses (table 4).

\section{MORBIDITY AND MORTALITY}

The 39 virus infections were associated with a wide range of symptoms. Two patients experienced severe infections (case 2, table 3; case 26 , table 4). Both died and viruses were isolated from the respiratory tract at necropsy. Five patients had a moderately severe infection (cases 1, 3, and 7, table 3; cases 30 and 33, table 4). Three were infections of the respiratory tract and two were alimentary tract infections.

Thirty five of the 81 bone marrow transplantation patients studied died, 18 due to recurrence of the underlying disease and three due to GVHD. Fourteen patients died of a variety of causes, including eight believed to have died due to an infectious agent. Permission for post mortem examination was given for seven patients, five of whom were allogeneic recipients. In the case of the remaining patient, who died of atypical pneumonia and bleeding, bronchoalveolar lavage and lung biopsy specimens were virologically examined six days before death and no virus was detected. Viruses were isolated from three of the seven patients (table 7), although only one patient was considered to have died due to the virus infection (case 5).

VIRUS ISOLATIONS IN PATIENTS WITH GVHD BUT NO SYMPTOMS OF VIRAL INFECTION

Seven patients with GVHD and no overt

Table 6 Seropositivity (No/\%) to herpes viruses in recipients before bone marrow transplantation

\begin{tabular}{lll}
\hline & \multicolumn{2}{l}{ Seropositivity } \\
\cline { 2 - 3 } Virus & Allogeneic & Autologous \\
\hline Cytomegalovirus & $16 / 31(51 \cdot 6)$ & $26 / 47(55 \cdot 3)$ \\
Herpes simplex virus & $20 / 23(86 \cdot 9)$ & $38 / 40(95 \cdot 0)$ \\
Varicella zoster virus & $25 / 27(92 \cdot 6)$ & $34 / 41(82 \cdot 9)$ \\
Epstein-Barr virus & $26 / 28(92 \cdot 9)$ & $36 / 40(90 \cdot 0)$ \\
\hline
\end{tabular}


Table 7 Bone marrow transplant recipients deaths undergoing virological investigations

\begin{tabular}{lllll}
\hline $\begin{array}{l}\text { Case } \\
\text { number }\end{array}$ & $\begin{array}{l}\text { Marrow } \\
\text { transplantation }\end{array}$ & $\begin{array}{l}\text { Survival after } \\
\text { transplantation }\end{array}$ & $\begin{array}{l}\text { Virus isolated } \\
\text { after death }\end{array}$ & Cause of death \\
\hline 1 & Autologous & 69 & Rhinovirus & ND \\
2 & Allogeneic & 22 & ND & $\begin{array}{l}\text { Cardiomyopathy (drug induced) } \\
\text { Pneumonitis, aetiology unknown }\end{array}$ \\
3 & Allogeneic & 187 & $\begin{array}{l}\text { Herpes simplex } \\
\text { virus }\end{array}$ & $\begin{array}{c}\text { Encephalitis and pneumonitis, } \\
\text { aetiology unknown }\end{array}$ \\
4 & Allogeneic & 256 & Cytomegalovirus & $\begin{array}{c}\text { Cytomegalovirus pneumonitis and } \\
\text { graft versus host disease }\end{array}$ \\
5 & Allogeneic & 76 & ND & $\begin{array}{c}\text { Pneumonitis (pneumocystis) } \\
\text { Septicaemia (staphylococci) }\end{array}$ \\
6 & Allogeneic & 100 & ND &
\end{tabular}

symptoms of infection each had a virus isolated at the time GVHD was diagnosed (table 8). No virus was detected in another 13 patients with GVHD who were similarly studied. Papovavirus in urine was the most frequently detected virus in those patients investigated with GVHD alone, occurring in five of the seven cases, all within the first five weeks after transplantation. Paired sera were available for four of these patients. Only one showed a definite serological rise to $\mathrm{BK}$ virus.

\section{Discussion}

This study was concerned primarily with the detection of virus infections in symptomatic bone marrow recipients. The major finding was that viruses had a minor role in morbidity in this centre and caused the death of only one patient.

Six of the $32(19 \%)$ allogeneic recipients had a symptomatic CMV infection during the study period. This rate is lower than those reported by other workers from allogeneic recipients. Gratama and coworkers reported CMV infection in 26 of $55(47 \%)$ patients. ${ }^{14}$ Similarly, Guyotat and colleagues documented CMV infection in 44 of $83(53 \%)$ patients within the first year of transplantation. ${ }^{10}$ In both these studies, however, patients were routinely monitored for $\mathrm{CMV}$ infection and no distinction was made between asymptomatic and symptomatic patients. Neither study mentioned whether prophylaxis with acyclovir was given.

Infection with CMV was shown solely in allogeneic bone marrow transplant recipients. CMV infection has been documented in autologous bone marrow recipients, although at a reduced level. ${ }^{15}$ These observations may reflect the severe conditioning treatment used in allogeneic bone marrow transplantation. Although there was no association between CMV infection and overt GVHD in this study, a subclinical graft versus host reaction may play some part in the reactivation of CMV in the allogeneic recipients. Six of seven CMV isolations were associated with a period of morbidity in the patient.

On occasions it may be difficult positively to correlate CMV infection with morbidity, particularly in the early period after transplantation when the patient may have numerous clinical problems including other microbial infections. One seronegative recipient (case 4, table 3) seroconverted to CMV despite receiving seronegative marrow and blood products. Precisely when the patient became infected was impossible to tell. The number of patients was too small to establish any pattern between CMV infection and serostatus of the donor and recipient. CMV infection occurred early in the period after transplantation, a finding in agreement with other workers. ${ }^{516}$

Despite a high prevalence of serum antibodies to $\mathrm{VZV}$ and $\mathrm{HSV}$, the rate of detectable infections with these viruses was low: $6.2^{\circ}{ }_{0}$ and $7.4^{\circ} \%$, respectively. In a multicentre study Watson reported a $40 \%$ incidence of zoster, $^{17}$ and Locksley and coworkers documented a rate of $16 \cdot 6^{\circ}{ }_{0}{ }^{18}$ If our patients had been studied for longer the incidence of zoster might have been higher. The low incidence of HSV infection contrasts strongly with a rate of $80 \%$ for seropositive marrow recipients published by other workers. ${ }^{19}$

The very low rate of $\mathrm{HSV}$ infection may reflect the prophylactic use of acyclovir. Furthermore, this may be a factor in the comparatively low rate of CMV infection found here. There is increasing evidence to support this hypothesis ${ }^{8}$ in particular a recent randomised placebo controlled trial showed that oral acyclovir significantly reduced CMV infection and disease in renal transplant recipients. ${ }^{20}$

Papovaviruses were detected by electron microscopical examination and therefore no differentiation between $\mathrm{BK}$ and JC viruses could be made. The allogeneic recipient found

Table 8 Virus isolations in bone marrow transplant recipients coincident with GVHD alone

\begin{tabular}{llll}
\hline Case number & Virus & Weeks after transplantation & Specimen \\
\hline 34 & Cytomegalovirus & 63 & Urine \\
35 & Papovavirus & 4 & Urine \\
36 & Papovavirus & 2 & Urine \\
37 & Papovavirus & 2 & Urine \\
38 & Papovavirus & 3 & Urine \\
39 & Papovavirus & 4 & Urine \\
40 & Coxsackie virus B3 & 1 & Nose and throat swab \\
\hline
\end{tabular}


to be excreting papovavirus coincident with clinical symptoms (fever) had a serological response to JC virus. Other workers have found BK virus to be the most frequently detected papovavirus in bone marrow transplantation. ${ }^{21}$ Unlike our study, however, these workers routinely monitored patients and used a more sensitive DNA hybridisation detection method. Haemorrhagic cystitis was not found in our patients and thus we were unable to confirm the observation of Arthur and colleagues $^{22}$ that papovaviruses are significantly associated with this condition.

Papovaviruses were the major viruses found in the separate group of patients with GVHD alone, although viruses were not detected in most patients. There was no definite association between CMV infection and GVHD in our patients.

Of the three patients in whom virus was detected at necropsy, only case 5 was considered to have died due to a virus infection. There was virological and histological evidence of CMV infection of the lung, no other pathogen was isolated, and thus CMV was believed to be the causative agent of the fatal pneumonitis. In case 1 , who died of acute respiratory distress of a bacterial aetiology, a rhinovirus was isolated from the upper but not the lower respiratory tract. A rhinovirus was also isolated from the upper respiratory tract one week before transplantation and from a sputum specimen 11 days before death. Unfortunately, it is not known if one or more rhinovirus types were involved as the viruses were not available for typing with specific antisera. Case 3 died of an idiopathic pneumonitis 187 days after bone marrow transplantation. CMV was isolated from urine specimens at 77 and 82 days before death, but no virus was isolated from tissues collected at necropsy.

Case 4, who died with encephalitis and pneumonitis and from whom HSV was isolated at necropsy, merits particular comment. Firstly, active HSV infection was never virologically documented during life. At necropsy HSV was detected in trachea, bronchus, left lung (immunofluorescence and culture), right lung, brain and spleen (culture alone). The pneumonia was unilateral and bronchopneumonia with abscess formation was found in the left lung. Although HSV was detected by immunofluorescence only in the left lung, it is difficult to know how much, if at all, the virus contributed to the pneumonia. HSV was isolated from the brain of the patient, but no viral antigen was detected by immunofluorescence in the part of the temporal lobe examined. Histological examination did not show the presence of virus-like inclusion bodies in any organ. Therefore the isolation of HSV from the brain, right lung, and spleen probably represents cross-contamination from the infected left lung, trachea, or bronchus via scalpel blades. Papovavirus was detected in the urine during life, coincident with GVHD. There was no histological evidence, however, to support a diagnosis of progressive multifocal leucoencephalopathy. Furthermore, the patient seroconverted to BK not JC virus.
Diagnosis of virus infection by measuring the serological response was found to be unreliable, confirming the observation of other workers. ${ }^{23}$ Whenever possible, a diagnosis of virus infection in bone marrow recipients should be made by detecting either viable virus, viral antigen, or viral nucleic acid.

In summary, this study has shown virus infections to be less of a clinical problem than suggested by other workers, and a rare cause of death. Prophylaxis with acyclovir may have influenced the rate of herpes virus infections and resulted in their lack of clinical prominence.

We are indebted to the North of England Cancer Research Campaign and the North of England Children's Cancer Research Fund for financial support; to the Department of Virology at the Royal Victoria Infirmary for virological diagnosis; and the nursing staff of Wards 13 and 16 South for the collection of specimens.

1 Thomas ED. Marrow transplantation for malignant diseases. J Clin Oncol 1983;9:517-30.

2 Bacigalupo A, Hows J, Gluckman E, et al. Bone marrow transplantation versus immunosuppression for the treatment of severe aplastic anaemia (SAA): a report of the EBMT SAA Working Party. Br J Haematol 1988;70: 177-82.

3 Meyers JD, Flournoy N, Thomas ED. Risk factors for cytomegalovirus infection after human marrow transplantation. J Infect Dis 1986;153:478-88.

4 O'Reilly RJ. Allogeneic bone marrow transplantation: current status and future directions. Blood 1983;62:94164.

5 Englehard D, Marks MI, Good RA. Infections in bone marrow transplant recipients. J Pediatr 1986;108:335-46. 6 Meyers JD, Thomas ED. Infection complicating bone marrow transplantation. In: Rubin RH, Young LS, eds. Clinical approach to infection in the compromised host. 2nd edition. London: Plenum Medical Book Company, 1988:525-56.

7 Saral R, Burns WH, Laskin OL, Santos GW, Lietman PS. Acyclovir prophylaxis of Herpes simplex virus infections. A randomized, double-blind, controlled trial in bone marrow transplant recipients. $N$ Engl J Med 1981;305: 63-7.

8 Meyers JD, Reed EC, Shepp DH, et al. Acyclovir for prevention of cytomegalovirus infection and disease after allogeneic marrow transplantation. $N$ Engl J Med 1988; 318:70-5.

9 Atkinson K, Meyers JD, Storb R, et al. Varicella zoster virus infection after marrow transplantation for aplastic anaemia or leukaemia. Transplantation 1980;29:47-50.

10 Guyotat D, Gilbert R, Chamel J, et al. Incidence and prognosis of cytomegalovirus infections following allogeneic bone marrow transplantation. J Med Virol 1987;23:393-9.

11 Sturdy PM, McQuillin J, Gardner PS. A comparative study of methods for the diagnosis of respiratory virus infections in childhood. J Hyg (Camb) 1969;67:659-70.

12 Gardner PS, McQuillin J. Rapid virus diagnosis. Application of immunofluorescence. (2nd edition). London: Butterworths, 1980.

13 Morris DJ, Lomax J, Craske J, et al. Effect of centrifugal enhancement of infectivity on the rapid detection of human cytomegalovirus in cell culture by immunofluorescence using a monoclonal antibody to an immediate early nuclear antigen. Serodiagn Immunother 1987;1:141-52.

14 Gratama JW, Middledorp JM, Sinniger LGF, et al. Cytomegalovirus immunity in allogeneic marrow Cytomegalovirus immunity in allogen

15 Pecego R, Hill R, Appelbaum FR, et al. Interstitial pneumonitis following autologous bone marrow transpneumonitis following autologous bone ma

16 Vilmer E, Mazeron MC, Rabian C, et al. Clinical significance of cytomegalovirus viremia in bone marrow transplantation. Transplantation 1985;40:30-5.

17 Watson JG. Problems of infection after bone marrow transplantation. J Clin Pathol 1983;36:683-92.

18 Locksley RM, Flournoy N, Sullivan KM, Meyers JD. Infection with varicella zoster virus after marrow transplantation. J Infect Dis 1985;152:1172-81.

19 Meyers JD, Flournoy N, Thomas ED. Infection with herpes simplex virus and cell-mediated immunity after marrow simplex virus and cell-mediated immunita

20 Balfour HH, Chace BA, Stapleton JT, Simmons RL, Fryol DS. A randomised, placebo-controlled trial of oral Fryol DS. A randomised, placebo-controlled trial of oral acyclovir for the prevention of cytomegalovirus disease in recipients

21 Arthur RR, Shah KV, Charache P, et al. BK and JC virus infections in recipients of bone marrow transplants. $J$ Infect Dis 1988;158:563-9.

22 Arthur RR, Shah KV, Baust SJ, et al. Association of BK viruria with haemorrhagic cystitis in recipients of bone marrow transplants. N Engl J Med 1986;318:230-4.

23 Panjuvanic DD, Ball MG, Berry NJ, et al. Virological and serological diagnosis of cytomegalovirus infection in bone marrow allograft recipients. J Med Virol 1985;16:357-65. 